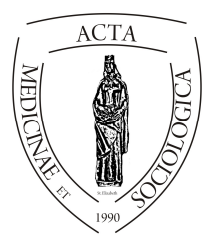

\title{
Romániai és magyarországi mezőgazdasági szövetke- zeti társaságok jogi és gyakorlati vonatkozásai
}

\author{
Csipkés Hajnalka-Szende
}

PhD hallgató, Babeș-Bolyai Tudományegyetem Szociológia Doktori Iskola, 400604 Kolozsvár, 21 Decembrie 1989 sugárút, 128.

\section{INFO ABSTRACT}

\begin{abstract}
Hajnalka-Szende Csipkés szende_csipkes@yahoo.com

\section{Keywords}

agricultural policy, cooperatives, legal background
\end{abstract}

Legal and practical references of Romanian and Hungarian agricultural co-operative associations. Accession to the European Union in Central and Eastern European countries has set new challenges in several social and economic areas.

Agriculture was one of the most important economic sectors that needed transformation during the integration process. European agricultural policy as well as agriculture and rural development programs are considered an effective tool to organize farmers into agricultural cooperatives. Therefore this study is researching the situation of cooperatives in Hungary and Romania.

\begin{tabular}{ll}
\hline Kulcsszavak & Absztrakt: Az Európai Unióhoz való csatlakozás a kelet-közép \\
agrárpolitikák, & európai országokat számos társadalmi és gazdasági területen új \\
szövetkezetek, & kihívások elé állította. A mezőgazdaság képezte az egyik legje- \\
az agrárszövetkezetek & $\begin{array}{l}\text { lentősebb gazdasági szektort, mely az integrációs folyamat so- } \\
\text { jogalapja }\end{array}$ \\
& rán átalakulásra szorult. Az európai agárpolitikák valamint a \\
& mezögazdasági és vidékfejlesztési programok hatékony esz- \\
& köze a mezőgazdasági szövetkezetekbe való tömörülés, ezért \\
& jelen tanulmány célja a magyarországi és romániai szövetkeze- \\
& tek helyzetének bemutatása. Követendő volna néhány nyugat- \\
& európai szövetkezeti modell, melyek megfelelő stimulánsok ha- \\
& tására jól müködő társulási lehetőségeket kínálnak a gazdák \\
& számára. \\
\hline
\end{tabular}

Ez a tanulmány a XI. Nyíregyházi Doktorandusz Konferencián (2017. 12. 01., Nyíregyházi Egyetem) elhangzott előadás alapján készült. 


\section{Bevezető}

Jelen tanulmány a mezőgazdasági erőforrásokat szövetkezeti szempontból tekinti át. Szabó (2006) szerint a szövetkezet egy olyan vállalkozási forma, melynek igénybevevői egyben tulajdonosai is annak, ugyanakkor igazgatják is azt, a haszonból pedig az igénybevétel alapján részesednek. A szövetkezeti társulások lényege a közösségi tulajdonon alapuló érdekérvényesítés. Szabó (2005) kiemeli, hogy „lényeges az úgynevezett hármas egység: tulajdonos (kockázatviselö) - irányító (a föbb döntéseket hozó) - használó (a szövetkezet szolgáltatásait igénybe vevő) megléte, amelynek értelmében a tagok egyszerre tulajdonosai a szövetkezetnek, tehát viselik a kockázatot, meghozzák a föbb döntéseket a (közös) vállalkozást illetően, és forgalmat bonyolítanak le a szövetkezettel, azaz igénybe veszik a szövetkezetet, amely a vállalkozás gazdasági tevékenységének az alapja" (Szabó 2005, 83).

A fenti definíciók értelmében határozza meg a szövetkezeteket a Szövetkezés Nemzetközi Alapelvei címet viselö dokumentum is ,,a szövetkezet önkéntesen egyesült személyek autonóm szövetsége, akik abból a célból szerveződnek, hogy közös gazdasági, társadalmi és kulturális szükségleteiket és igényeiket egy közös tulajdonú és demokratikusan vezetett vállalkozás segítségével elégítsék ki” (Bak 2014, 22).

A szövetkezet tehát, sajátos gazdasági és adminisztratív jellemzőkkel bíró önszervező társulási forma, amelynek jogi szabályozása az Európai Unió szintjén már az 1980-as években felmerült (Nagy 2013).

Romániában gazdasági ösztönző intézkedések hiányában az Európai Unió átlagosan fejlettebb gazdasági szintjéhez való felzárkózás folyamatát nem jellemzi hatékonyság és nehézkesen halad a termelök összefogása is. A szövetkezet gondolata a múlt rendszer termelöszövetkezeteivel cseng össze, ezért a termelők és a gazdák egy része fél az együttmüködés bármilyen formájától, illetve a jogi kötöttségektől, melyek a hivatalos müködési formák velejárói (Hunyadi 2007). Az 1989 utáni tranzíciót a szocialista-kommunista tervgazdálkodásról a piacgazdaságra való sajátos átmeneti helyzet jellemezte (Albert-Lőrincz 2017), mely során a romániai gazdák nem részesültek a mezőgazdasági szövetkezetek nyújtotta előnyökből, támogatásokból. A helyzeten az Európai Unióhoz való csatlakozás sem segített, így elmaradtak a lehívható támogatások előnyei, melyek biztos és állandó értékesítési lehetőséget, esetenként magasabb árat, a piaci ellensúlyozást, biztosabb jövedelmi forrást teremthettek volna.

A 2011-2012-es Európai Bizottság Support for Farmers Cooperatives (A gazdálkodók szövetkezetének támogatása) néven ismert felmérése kimutatta, hogy a tagállamok többségében a szövetkezetek adta lehetőségeket különösen az újonnan csatlakozott tagállamok, mint például Magyarország és Románia nem használják ki (Szabó, Baranyai és Barta 2014).

A felmérés Magyarországra vonatkozóan megjegyzi, hogy léteznek általános müködési problémák a magyar mezőgazdaságban a rendszerváltást követően is, mint például egy stabil gazdasági, politikai és etikai biztonság hiánya, magas gazdasági bizonytalanság, különböző szövetkezeti rendelkezések tisztázatlansága, valamint a mezőgazdasági termelésből származó alacsony jövedelmi lehetőségek. A felmérés a mezőgazdasági szövetkezetek alacsony számának okát a kommunista rendszer utóhatásának tulajdonítja (Szabó et al. 2014). 
Juhász a magyar mezőgazdaság és vidék, illetve a szociális és helyi gazdaság fejlesztésének egyik kulcselemeként határozza meg a szövetkezetek terjedését és müködését, különös tekintettel az új típusú szövetkezetekre (Juhász 2013).

Románia esetében is hasonló okok miatt alacsonyak ezen társasági formák, habár a 2009-2011-es évek között népszerübbé váltak különböző fiskális kedvezményeknek és a könnyebben lehívható uniós finanszírozásoknak köszönhetően. A fellendüléshez hozzájárul a média széleskörü népszerüsítési tevékenysége is (Călinescu 2012), viszont érdemben nem történt meg a fejlett gazdaságokhoz való felzárkózás.

A szövetkezeti forma előnyeinek ellenére úgy Magyarország, mint Románia elmarad a többi EU-tagállamtól a szövetkezeti hálózat fejlettségét tekintve. Ennek magyarázata a kommunizmus kulturális hagyatékának tudható be, mely napjainkban is gátolja a társadalom tényleges demokratizálódását (Erdős 2011). Egy újabb felmérés szerint, melyet a General Committee for Agricultural Cooperation (COGECA) nevü Európai Uniós szervezet 2014-ben hozott nyilvánosságra, Magyarországon 1116 agrárszövetkezet létezett, míg Romániában mindössze 68. Összehasonlításként megemlítenénk, hogy Olaszországban 5834, Spanyolországban 3844, Németországban 2400 , Franciaországban pedig szintén 2400 nyilvántartott mezőgazdasági szövetkezet müködik (Mezőgazdasági szövetkezetek fejlődése az Európai Unióban, 2014).

\section{Müködő nyugati-európai szövetkezeti modellek}

„A múlt század közepén létrehozott Európai Gazdasági Közösség (Közös Piac) első fejlődési szakaszában (1951-1957) olyan gazdaságpolitikai alapelveket fektettek le, amelyeknek célja az AEÁ életszínvonalának elérése vagy megközelítése volt. Ehhez gazdaságélénkítő stratégiát kellett kidolgozniuk" (Albert-Lőrincz és Albert-Lőrincz 2014:7).

Megjegyzendő, hogy ezen stratégiák különösen az Európai Gazdasági Közösséget (EGK) alapító országok (Belgium, Németország, Franciaország, Olaszország, Luxembourg és Hollandia) (Albert-Lőrincz 2014) közös agrárpolitika törekvései túlnyomórészt hozzájárultak a jelenlegi jól müködő szövetkezeti modell létrejöttéhez.

A fentieknek tulajdonítható, hogy a nyugat-európai országokat magas mezőgazdasági szövetkezeti számok jellemzik.

Mindebből az következik, hogy a jól müködő gazdaságok hatékony termelési formája a szövetkezet. A szövetkezet előnye a közös beszerzés, a nagy volumenben történő minőségű termékértékesítés és a termelőket kiszolgáló infrastruktúra létrejötte (Bors 2008).

Ahhoz, hogy Magyarország és Románia helyzete javuljon szövetkezeti téren, szükségszerü volna a nyugati szövetkezeti modellek átültetése úgy a nemzeti agrárpolitikákba, mint a köztudatba.

A nyugat-európai mezőgazdaságban a szövetkezetek valósítják meg azokat a feladatokat, amelyeket családi gazdaságokban nem lehet nyereségesen folytatni vagy amely tevékenységek kivitelezése az egyéni vállalkozók számára túlzottan megterhelőek volnának. Kezdetben az Európai Unióban a szövetkezetek célja az eredményes tej-, és a hústermelés volt, melyek jelenleg is fontos szerepet játszanak (Bors 
2008). A termelési sikerhez az Európai Unió által folyósított támogatások is jelentősen hozzájárultak.

Németországban majdnem minden mezőgazdasági termelő tagja egy vagy több szövetkezetnek, ezért magas számban elterjedt társulási forma. A német szövetkezeti törvénykezést illetően a kezdeti szabályozás fakultatív jelleggel bírt, tehát a szövetkezet szabad döntésétől függött az, hogy a szövetkezeti törvény rendelkezéseit betartva alakul-e meg és ily módon megszerzi-e a törvényben foglalt, bejegyzett müködési formát megillető jogokat. Amennyiben a gazdák nem a szövetkezeti törvény értelmében alapított társulási formát választottak, nem rendelkeztek a törvényes szövetkezeti előnyökkel (Réti 2012). Fontosabb jogszabályok az 1889-tól hatályos német Szövetkezeti törvény, ezt követte az 1889-ben megfogalmazott jogszabály, mely a vagyonjogi elöírásokra tért ki, melyet az 1973-ban elfogadott kodifikáció egészített ki (Réti 2012).

A német szabályozás a nyitott tagság, az önsegély, a vásárlás arányában történő visszatérítés, valamint a korlátozott tőkekamat elvét alkalmazza. A szövetkezeti-tőke változó, amely vagyonjogi jellemző sajátosságot kölcsönöz más jogi formákkal szemben. A szövetkezeti cél a tagok gazdasági elömenetele. (Réti 2012). Müködésük során a német szövetkezetek kötelesek töketartalékot felhalmozni, valamint a nyereség függvényében a tagok kötelesek több üzletrész jegyzésére (Réti 2012). Így biztosított a szövetkezet folyamatos erősödése és a tagok érdekeltségének fokozása.

Az üzletrész szigorú alaki szabályokhoz kötött, melynek célja a forgalombiztonság és a hitelező védelme, valamint a szövetkezet piaci pozíciójának erősítése. Az üzleti vagyonilletőség a nyereség és veszteség arányában változó tételt jelent a német szabályozásban (Réti 2012).

A szövetkezeti tagok önkéntesen együttmüködnek egy közös vállalkozásban, azért, hogy különböző gazdasági aktivitásokhoz és a nyereségekhez jussanak, mint például kedvező közös beszerzési és értékesítési feltételekhez, ez pedig a költségek csökkentését is jelenti. A szövetkezetekben a tagok megtartják az egyéni függetlenségüket. A mezőgazdasági szövetkezetek bizonyos feltételek mellett a társasági adó, iparüzési adó és a vagyonadó kötelezettsége alól mentesek (Kühl 2012).

Franciaországban ,az első mezőgazdasági géphasználati szövetkezetek (Coopérativesd' Utilisation de Matériel Agricole - CUMA) a második világháború után alakultak a Marshall-terv idején, az 1947-es szövetkezeti törvényt követően" (Simon 2007, 335). A mezőgazdasági termelés növelésére és modernizálására irányuló erőfeszítések serkentették a szövetkezeti társulási forma elterjedését, és ez a folyamat napjainkban is tart. „Céljuk a gépek, berendezések, épületállomány vagy szolgáltatások közös hasznosítása a jövedelmezőség javítása érdekében” (Simon 2007, 335).

Franciaország területén egyik legfontosabb csoportos gazdálkodási típus az úgynevezett GAEC (A Közösen Gazdálkodó Csoportok, Groupement agricole d'exploitation en commun). Jogilag egyesületek, de a szövetkezeti alapelvek szerint mükődnek. Célja, hogy a mezőgazdasági munkákat közösen végezzék, a társult tagok csak természetes személyek lehetnek, számuk 2 és 10 között mozog, ugyanakkor házastársak nem hozhatnak létre ilyen együttmüködési formát (Bors 2008). A szervezetben a közös munka a termelési tevékenység egészére vagy csak egy részére terjed ki, de a szabályozás értelmében a csoport nem lehet egyes tagok részére teljes, mások 
számára részleges. A szervezet vezetése kollegiális, de meg kell bízni egy tagot a csoport képviseletével. Adózási, társadalombiztosítási hitel és kedvezmény vonatkozásában a tagok egyéni gazdálkodóknak minősülnek (Bors 2008).

Már az 1920-es általános francia Fiskális törvénykönyv ingatlanadó mentességet nyújtott olyan szövetkezetek részére, mely tartósan és kizárólag az ingatlanjukat mezőgazdasági célokra használják (Filippi 2012). Később az 1948-as dekrétumban a mezőgazdasági szövetkeztek a társasági adó mentességre jogosultak. Az 1975-ös törvény pedig vagyonadó mentességet irt elö a mezőgazdasági szövetkezetek javára abban az esetben ha, maximum három alkalmazottal rendelkeznek, vagy ha tevékenységük tárgya vidékfejlesztés vagy mezőgazdasági anyagok felhasználása (Filippi 2012).

Olaszország a statisztikák szerint az egyik legtöbb szövetkezeti formával rendelkező államok közé sorolható. A 228. számú 2001-es a mezőgazdasági szektor korszerüsítéséről szóló törvény a mezőgazdasági szövetkezeteket az olasz agrárpolitika fejlődés kulcsszereplőinek tekinti, ezért különböző pénzügyi és jogi előnyökhöz jutatja. A törvény agrár-élelmiszeripari lánc kialakulását is stimulálja (Bono 2012). Az ezt követő 6. számú 2003-as a társasági jog reformjáról szóló törvény tisztázza a termelői szövetkezetek szabályozási keretét. 2004-ben az olasz gazdálkodók támogatásokban részesültek a mezőgazdasági termékeket ért természeti katasztrófák vagy egyéb csapások esetén (Bono 2012).

Az olasz törvény adókedvezményeket biztosít szövetkezetek számára ezek típusától függően. Formától függően a társasági adókedvezmény 20-70\%-ig terjed. Olasz nemzeti egyesületek segítik a szövetkezeti rendszer müködését. Példaként megemlítenénk: Confederazione Cooperative Italiane-Confcooperative; Lega Nazionale delle Cooperative e Mutue-Legacoop; Associazione Generale Cooperative Italiane-AGCI; Unione Nazionale Cooperative Italiane - UNCI; Unione Italiana Cooperative - UNICOOP. Minden ilyen egyesület keretén belül létezik egy agrár-élelmiszeripari szövetkezetekre szakosodott részleg, mint például: Confcooperative - Fedagri; Legacoop Agroalimentare; AGCI-Agrital; ASCAT UNCI; UNICOOP Agricoltura (Bono, 2012). A mezőgazdasági szövetkezetek nagyrésze a fent említett nemzeti egyesületekkel társult. A 2005-ös 231. számú törvény hatályba lépésével a Mezőgazdasági, Élelmezési és Erdészeti Politikák Minisztériuma mezőgazdasági együttmüködési figyelőt indított (Italian agricultural cooperation Observatory), mely azokat a szövetkezetek adatait elemzi, melyek nemzeti szövetségekhez is társultak. Célja az agrár-élelmiszeripari szövetkezetek tanulmányozása ahhoz, hogy a legmegfelelőbb információkban, támogatásokban részesítse ezeket a vállalkozási formákat (Bono 2012).

Dániában a mezőgazdasági termelők piacra jutásának fő eszköze a szövetkezeti társulás - mivel a termelés inkább egyéni jellegü. A feldolgozóipar a szövetkezeti tagok tulajdonában van, így továbbfejlesztési kérdésekben szabadon dönthetnek (Szerelmey 2008).

A dán farmerszövetség létrehozott egy szakértői csoportot, amely a tagokat segíti a pályázatok lehívásában. A gazdák egy számítógépes pályázatkezelö rendszert müködtetnek, hetente megjelenő újságokat és weboldalt üzemeltetnek, gyakori szakmai találkozókat és szaktanácsadásokat rendeznek. A termelök többsége kis- és középvállalkozásba, esetleg családi vállalkozásokba tömörül. Az általuk előállított mezőgazdasági termékek valójában csak nyersanyagnak bizonyulnak, ezért élelmiszer- 
ipari feldolgozásra van szükség, mely egyúttal a termékbegyüjtést is ellátja (Szerelmey 2008). A megtermelt „készterméket” a farmer föként értékesíto és feldolgozó szövetkezeteken keresztül értékesíti, tehát a dán gazdaságra nem jellemzőek a közösen termelö szövetkezetek (Szabó 2007).

A dán modell sajátosságai a következők: a gazdálkodó tulajdonosa a földnek és a feldolgozásnak, a szövetkezet érdekközösségi intézmény - fö szerepe az árú piacra juttatása. A termelés minőségi és ellenőrzött, a technikai színvonalat folyamatos fejlesztés garantálja. A társulásoknak egyféle célja van, ezért nagy a tevékenységi kötődés. A tulajdonformát az oszthatatlan közös vagyon jellemzi. Mindezek által a dán rendszer nagy piaci részesedést biztosít (Szerelmey 2008).

Mindegyik fejlett tagállam különös figyelmet fordít a szövetkezeti formákra. Legtöbbször fiskális stimulánsokhoz folyamodnak, melyek adókedvezményeket vagy esetenként akár adómentességet is jelenthet (Németország, Franciaország esete), a gazdák segítségére nemzeti szervezeteket hoznak létre (Olaszország) valamint korszerü információnyújtást biztosítanak (Olaszország, Dánia).

\section{Következtetések}

Magyarországon és Romániában az Európai Unióhoz való csatlakozás hatására megfigyelhető a szövetkezeti jog területén is harmonizációs törekvések. Általánosságban elmondható, hogy a kilencvenes, de még a kétezres években sem sikerült érdemben elöremozdítani a szövetkezeti örökséget. Törvényhozói szinten hiányoztak a kellő gazdasági vagy akár fiskális ösztönzések, a magyarországi szövetkezeti jogot föként a következetlenség, a romániai szövetkezeti jogot inkább a látszatintézkedések jellemezték. Mindkét országban az utóbbi években a statisztikai adatok szerint emelkedett a szövetkezetek száma. A gazdák és termelők felfogása azonban nem tudott túllépni a negatív kommunista örökségen.

Meglátásunk szerint a magyar és román viszonyokban alapjában véve a dán modell alkalmazása volna a legkézenfekvőbb (mely az értékesítésre és informálásra helyezi a hangsúlyt), a francia modell szerinti jelentős adókedvezményekkel, valamint a német modell szerinti kötelező részesedésnöveléssel, hogy a gazdák is fokozottan érdekeltek legyenek a szövetkezeti tevékenységeikben.

\section{Irodalomjegyzék}

1. Albert-Lörincz Cs. (2014): Diminishing national sovereignty affecting EU member states' citizenship? Globalization and Intercultural Dialogue. Multidisciplinary Perspectives. ARHIPELAG XXI PRESS. http://www.upm.ro/gidni/GIDNI-01/GIDNI\%2001\%20-\%20Law.pdf, (letöltés idöpontja 2017. november 17.)

2. Albert-Lörincz M., Albert-Lőrincz Cs. (2014): Kifelé a multikulturális térbe. Magiszter, XII. évfolyam, 3. szám, 6-15. ISSN 1583-6436 
3. Albert-Lőrincz Cs. (2017): Szociálpolitikai alapok és a jóléti perspektívák térvesztése. Kolozsvári Egyetemi Kiadó.

4. Bak K. (2014): A nemzetközi szövetkezeti alapelvek érvényesülése a 2013. évi V. törvény szövetkezetekre vonatkozó rendelkezéseiben. Agrár- és Környezetjog 16. 20-32. http://epa.oszk.hu/01000/01040/00018/pdf/EPA01040_agrar_es_kornyezetjog_2014_16_020-032.pdf, (letöltés időpontja 2017. november 17.)

5. Bono, P. (2012): Support for Farmers' Cooperatives: Country Report Italy. Wageningen UR. http://edepot.wur.nl/244801, (letöltés időpontja 2017. november 17.)

6. Bors R. (2008): Az üzemi struktúra fejlődésének irányai az EU tagországokban és Romániában. PhD Thesis. Gödöllő.

https://szie.hu//file/tti/disszertacio/Bors_Reka_ert.pdf, (letöltés időpontja 2017. november 17.)

7. Călinescu, D. (2012): Support for Farmers' Cooperatives: Country Report Romania. Wageningen UR. http://edepot.wur.nl/244812, (letöltés időpontja 2017. november 17.)

8. Erdős Bognárné M. (2011): From Ideology to Eidos: Recovering from State Socialism in Hungary. AUDEM: The International Journal Of Higher Education And Democracy. 2:(1) pp. 5-22.

9. Európai Bizottság (2012): A közös agrárpolitika Partnerség Európa és a gazdálkodók között.

http://ec.europa.eu/agriculture/cap-overview/2012_hu.pdf, (letöltés időpontja 2017 november 17)

10. Filippi, M. (2012): Support for Farmers' Cooperatives: Country Report France. Wageningen UR.

http://edepot.wur.nl/244795, (letöltés időpontja 2017. november 17.)

11. General committee for agricultural cooperation (COGECA). (2015): Mezőgazdasági szövetkezetek fejlődése az Európai Unióban.

http://www.europarl.europa.eu/meetdocs/2014_2019/documents/agri/dv/copacogecareport/copa-cogecareport_en.pdf, (letöltés időpontja 2017 november 17)

12. Hunyadi A. (2007): A különböző szövetkezeti tipusok és a szövetkezeti értékrend kialakulása. Kolozsvár: Romániai Magyar Közgazdász Társaság.

13. Ilyés F. (2015): Regionális gazdasági együttmüködés szövetkezeti keretek között-székelyföldi modellek-doktori értekezés. PhD Thesis. Pécs.

http://ktk.pte.hu/sites/default/files/hir_mellekletek/2015/06/ilyes_ferenc__disszertacio.pdf, (letöltés időpontja 2017. november 17.)

14. Juhász G. (2013): The Role and Importance of Social Economy in the Development of Local Community and Economy and Regional Convergence. In: Humán Innovációs Szemle. 1-2. szám. 38-45. p

15. Kühl, R. (2012): Support for Farmers Cooperatives. Country Report German. http://edepot.wur.nl/244796, (letöltés időpontja 2017. november 17.)

16. Nagy K. (2013): Az Európai Szövetkezet statútumáról (SCE) szóló tanácsi rendelet és a hatályos magyar szövetkezeti szabályozás vagyonjogi rendelkezéseinek összehasonlító jogi elemzése. Agrárjogi Tanszék. http://epa.oszk.hu/02300/02363/00019/pdf/EPA02363_THEMIS_2013_jun_306-329.pdf, (letöltés időpontja 2017. november 17.) 
17. Réti M. (2012): Az európai szövetkezeti szabályozás fejlődéstörténetéről. Szövetkezeti Kutató Intézet. http://www.szovetkezetikutato.hu/kozlesre.php, (letöltés időpontja 2017. november 17.)

18. Simon S., (2007): Nyugat-Európa legelterjedtebb szövetkezeti modelljei. In: Sómai, J. (ed.) Szövetkezetek Erdélyben és Európában. Kolozsvár: Romániai Magyar Közgazdász Társaság.

19. Simon S. (1999): A szövetkezeti törekvések múltja és jelene. Nemzetpolitikai szemle, 1(15).

20. Szabó G. G. (2005): A szövetkezeti identitás - egy dinamikus megközelítés a szövetkezetek fejlődésének gazdasági nézőpontú elemzésére. Közgazdasági Szemle 81-92.

21. Szabó G. G. (2006): “Co-operative identity”: A theoretical concept for economic analysis of practical co-operation dynamics. Studies in Agricultural Economics 105. 5-22.

22. Szabó G. G. (2007): Az európai mezõgazdasági szövetkezeti modellfejlõdés Dánia és Hollandia példáján keresztül bemutatva. In: Sómai, J. (ed.) Szövetkezetek Erdélyben és Európában. Kolozsvár: Romániai Magyar Közgazdász Társaság.

23. Szabó G. G., Baranyai, Zs., Barta, I., (2014): Sustainability of Emerging Agricultural Co-operatives in the New Member States of the EU: Hungarian Experience. Budapest.

24. Szeremley B. (2008): A dán szövetkezeti modell. Szociális Szövetkezetek Országos Szövetsége. http://szoszov.hu/szeremley-bela-a-dan-szovetkezeti-modell, (letöltés időpontja 2017. november 17.)

\section{Jogszabályok}

2003. évi CV. Törvény az új szövetkezetekröl szóló 2000. évi CXLI. törvény módosításáról. 